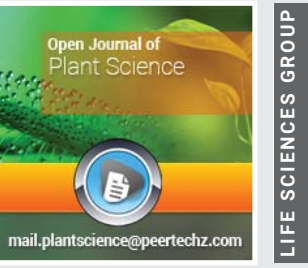

\title{
Chemical composition and in vitro digestibility of some
}

\section{range plants}

\section{Musa Ahmed Musa Tibin'1, Badreldeen Mohammed Musa Ibrahim², Suleiman Eshag Mohamed Abdalla ${ }^{3}$, Yahia Ibrahim Mohammed Abutaba ${ }^{4}$, Jumaa Barram Jadalla ${ }^{5}$ and Mohammed Alhadi Ebrahiem ${ }^{5 *}$}

\author{
'Department of Animal Production, Faculty of Natural Resources and Environmental Studies, \\ University of Al Salam Afula, Sudan \\ ${ }^{2}$ Ministry of Production and Economic Resources, North Kordofan State, Sudan \\ ${ }^{3}$ Department of Animal Production, Faculty of Agricultural Sciences, University of Dallanj, Sudan \\ ${ }^{4}$ Department of Forest and Range, Faculty of Natural Resources and Environmental Studies, University \\ of Kordofan, Sudan \\ ${ }^{5}$ Department of Animal Production Faculty of Natural Resources and Environmental Studies, University \\ of Kordofan, Sudan
}

Received: 13 September, 2021

Accepted: 30 September, 2021

Published: 01 October, 2021

*Corresponding author: Mohammed Alhadi Ebrahiem, Department of Animal Production Faculty of Natural Resources and Environmental Studies, University of Kordofan, Sudan, E-mail:mahaali5656@gmail.com

ORCID: https://orcid.org/0000-0003-3545-1242

Keywords: Chemical Composition; In vitro digestibility; Range plants; Vigna sunhum; Andropogan gayanus; Pennisetum pedicelatum; Shoenfeldia gracilis; Stylothanis flavicans

Copyright: () 2021 Musa Tibin MA, et al. This is an open-access article distributed under the terms of the Creative Commons Attribution License, which permits unrestricted use, distribution, and reproduction in any medium, provided the original author and source are credited.

https://www.peertechzpublications.com

\section{Check for updates}

\section{Abstract}

This study was carried out to determine chemical composition and in vitro dry matter and organic matter digestibility of range plant species of the area. Samples were collected from range lands at full maturity stage, dried under shade and subjected to chemical analysis and dry matter and organic matter in vitro digestibility for Vigna sunhum, Andropogan gayanus, Pennisetum Pedicelatum, Shoenfeldia gracilis and Stylothanis flavicans were determined. The data was analyzed via analysis of variance and differences among means were determined using Least Significant Difference (LSD) test. The results showed that the legumes (Vigna sunhum and Stylothanis flavicans) were significantly higher $(\mathrm{P} \leq 0.01)$ in their crude protein content and the percentage of crude protein respectively was $13.4 \%$ and $10.00 \%$ while the grasses were significant ( $\mathrm{P} \leq 0.05$ ) higher in Crude Fibre (CF), ash, Acid Detergent Fibers (ADF) and Neutral Detergent Fibers (NDF). Crude fiber \% values were $41.78,43.37$ and $46.07 \%$ for Pennisetum Pedicelatum, Andropogan gayanus and Shoenofeldia gracilis, respectively. The acid detergent values were $53.85,47.74$ and 53.39 for the three weeds. $(P \leq 0.05)$, while the ratio of neutral detergent was significantly higher $(P \leq .05)$ in grasses than in the two legume species; $87.22,82.35$ and $88.99 \%$ for the three grasses respectively. Similarly higher in vitro dry matter and organic digestibility coefficients were obtained from legume species than grasses. The study concluded that, the studied grasses were higher in fiber content and lower in their protein content but, legumes grasses (Vigna sunhum, Pennisetum Pedicelatum and Stylothanis flavicans) had high nutritive value and in vitro digestibility which may provide ruminants with the needed protein and energy.

Range lands comprise $26 \%$ of the world's total land area and $80 \%$ of agricultural land, and represent a wide variety of ecosystems $[1,2]$. For millennia grasslands have been one of the foundations of human activities and civilizations by supporting production from grazing livestock. This is still the situation, particularly for developing countries including Sudan where $68 \%$ of range lands are located. From the perspective of animal scientists, the utilization of range lands has historically focused on their use for livestock, particularly to produce meat and milk and to lesser extents fiber and draught power. This has arguably been at the expense of many other current and potential functions of range lands, and of many peoples who have historically derived their livelihoods and cultures from the same those natural resources [3,4]. However, perspectives and perceptions of the most appropriate roles and functions of range lands have been changing in recent decades. There has been recognition that there are numerous regional, national and global issues with which utilization of range lands are inextricably linked. These include the function of range lands to provide social and cultural needs for many rural societies, 
their role in reducing Greenhouse Gas (GHG) emissions, as water catchments, and the preservation of ecosystem biodiversity [3]. At the same time increased global demand for food must be met without unacceptable adverse effects (Food and Agriculture Organization $[4,5]$. Solutions to such issues are complicated by the need to meet the short term and long-term needs of those whose livelihoods depend on range lands.

There are more than 800 million in the world with very low income, and an additional 200 million in the more marginal arid and semi-arid areas, who are highly dependent on range grasslands for their livelihoods [4,6-8]. Because range lands are of such major global importance there are compelling reasons why they need to be better managed in order to best fulfill various functions. Knowledge is often lacking, particularly for tropical range lands in which our country lies. The knowledge that is available from the much more extensive studies of temperate range ecosystem often cannot be directly applied to tropical grass range lands. Optimal management of tropical range lands is challenging, especially given the diversity of agro-ecological contexts, the animal production constraints and soil-plant-animal interactions.

Optimal management for defined production, environmental and social targets will generally include inventories and assessments of the grasslands and grazing animals available and knowledge of the important herbage-animal relationships. The most important part that is tackled in this study is the assessment of nutritive value of some highly selected that are highly palatable hence selected and heavily grazed. This is essential for development of improved methods that are desirable to evaluate the current status and the potential of range lands' utilization systems and to guide management and may recommend domesticating some species.

As rangelands are communally used in Sudan in general and North Kordofan in particular, grazing areas are overstocked, continuously overgrazed. The livestock species usually select most palatable species and this leads to change of plant composition drastically. The annual range inventory conducted domination of unpalatable flora species and decreased population of palatable species [9]. The plant selected for this study are among most species that are subjected to heavy grazing and reduced sharply in plant composition. The overall objective of this study is to assist for improved sustainable methods for range lands' utilization in the State and the country.

\section{Materials and methods}

\section{The study site}

The study commenced on $5^{\text {th }}$ November and until first of December 2019 at the University of Kordofan farm in the city of Elobeid, which lies between the longitude $\left(29^{\circ}-34^{\prime}, 30^{\circ}-30\right.$; East) and the latitudes $\left(12^{\circ}-25^{\prime}, 13^{\circ}-30^{\prime}\right.$ North) with an area of $8080 \mathrm{~km}^{2}$. This City is the capital of Sheikan locality and North Kordofan State. Sheikan is characterized by undulating plains, depressions; sand covered with hilly areas and some mountain clusters. There are three climatic regions that cover North Kordofan State. These are dry, semi-arid dry and low rainfall savanna on sand areas where the study samples were collected from. The long term average rain is between $250-400 \mathrm{~mm}$. The maximum temperature is $40^{\circ}-42^{\circ} \mathrm{C}$ and the minimum is $13^{\circ} \mathrm{C}$ In the semi-arid region, rainfall is between $300-600 \mathrm{~mm}$ and the maximum temperature is $39^{\circ} \mathrm{C}$.

The humidity reaches 1175 during the dry season. In the autumn, the air humidity reaches $65-67 \%$ lobeid Meteorology Department office, 1999). Rainfall starts as sporadic showers in May and becomes regular from June to October. It is usually heavier in July and reaches peak in August before declining in September to reach its lower pattern in October. Temperatures are modified by rain at this time though it is hot and humid in general. Temperature and precipitation drops from the amount of evaporation in July and August and the highest rainfall recorded in 2010 was $620 \mathrm{~mm}$ (Sheikan locality, 2011).

This city is also considered the largest market for gum Arabic, as primary and important market of livestock brought from different parts of western and Southern Sudan in a continuous movement of the presence of different types of animals. There are some food industries and Agro-industrial companies such as vegetable oil production and flour mills (Sheikan locality, 2011). Elobeid Petroleum Refinery is set at $10 \mathrm{~km}$ from the city center. In general this city is a main marketing city for the country. Rural areas are farming and livestock producing areas.

Ligneous species are dominantly comprised of Hashab (Acacia senegal), Marrekh (Boscia senegalensis) and Seyal (Acacia tortilis) in the northern regions. Southern and central parts are covered with desert palm (Balanites agyptiaca), Sidr (Ziziphus spinachristi), tebeldi (Adansonia digitata) habeel (Combretum cordofanum), kitr (Acacia mellifera), ghobeesh (Quiera senegalensis ), Haraz (Faiherbia albida ), Arrad (Albizzia amara), Aradaib (Tamarindus indica) and many other trees and shrubs species of the zones indicated above. The under storey is dominantly covered with herbs such as Alysicarpus monilifer (Fraisha), Zornia gleochidiata (lisaig), Cassia obtusiflora (Kawal), Cassia occidentals (Soreib), Amaranethesis flavicans (Lisan eltair), Blepharis linarrifolia (Beghail) and many others. Grasses dominant in this are Eragrostis tremula (bino), Aristida pallida (gaw), Cenchrus biflorus (Huskaneet khashin), C. setigrus (Huskaneet Naeem) Pennisetum pedicellatum (Umdofofo) and others[9],

\section{Sampling the biomass of the studied species}

Plant biomass of the following species was harvested at full maturity stage: grass species among them included Schoenfeldia gracilis Danabelnaga, Andropogon gayanus Abuelrakhees and Pennisetum pedicellatum Umdofofo while Sylothansis flavicans Natasha and Vigna sunhun Lubia elghazal were among leguminous species. The biomass was cut at $5 \mathrm{~cm}$ height, sun dried and stored for chemical analyses. In vitro dry matter and organic matter digestibility was determined for the biomass of the species mentioned.

\section{Chemical analysis}

The plant species biomass mentioned in previous section 
was analyzed using proximate analysis as described by the Association of the Official Analytical chemists [10] and forage fiber analysis was done according to Terrie [11]. In Vitro dry matter and organic matter was determined according to Goering and Van Soest [12].

\section{Chemical analysis determents and their importance for animal nutrition}

Dry Matter: The determination of Dry Matter (DM) is the most common procedure carried out in nutrition laboratories because plant feedstuffs may vary in water content. The amount of water content must be known to permit comparisons of different feeds. DM is determined by drying the test material at $105^{\circ} \mathrm{C}$ overnight in an oven. DM is then determined by the following calculation:

Dry weight $/$ fresh weight $* 100=\%$ DM.

Crude Protein (CP): The procedure to estimate crude protein was developed by a Danish chemist, Johan Kjeldahl and is commonly known as "Kjeldahl" procedure. The Kjeldahl analysis depends on the measurement of Nitrogen $(\mathrm{N})$ in the test material. To convert the measured $\mathrm{N}$ content of the test material to crude protein, a calculation factor of 6.25 ( $\mathrm{N} \mathrm{x} 6.25)$ is applied. This is based on the fact that all proteins contain about $16 \% \mathrm{~N}(100 / 16=6.25)$ or $16 \mathrm{~g}$ of $\mathrm{N}$ comes from $100 \mathrm{~g}$ protein, or $1 \mathrm{~g}$ of $\mathrm{N}$ is associated with $100 / 16=6.25 \mathrm{~g}$ of protein.

Nitrogen $(\mathrm{N}) * 6.25=$ Crude Protein $(\mathrm{CP})$

\section{Ether extract}

Ether-soluble materials in feed include different organic compounds that are soluble in organic solvents. In animal feeds, ether extract may include fats, fatty acid esters, and fatsoluble vitamins and hence are often referred to as crude fat. The primary goal of ether extracts is to isolate the fraction of the feedstuff that has a high caloric value. A portion of the dried feed sample is boiled in ether (organic solvent) for four hours. Since fats are soluble in ether, ether extract is equivalent to fat. Provided the ether extract contains fats and fatty acid esters, this approach is valid. However, in samples that contain high levels of other compounds soluble in organic solvents, such as plant waxes or resins, it may not give a true estimate of feed caloric value. However, this error is generally small in typical animal feedstuffs. Overall, this test does not indicate anything about the quality of the fat in the feed.

\section{Ash}

Ash is the residue remaining after all the organic nutrients have been burned off or oxidized completely in an oven at $500^{\circ}$ to $600^{\circ} \mathrm{C}$ for two to four hours. Nutritionally, ash values have little importance, although high values may indicate contamination (e.g., soil) or dilution of the feed sample with limestone or salt. Ash values obtained are cumulative of all the mineral elements combined together. High temperatures used for burning may cause loss of some volatile elements such as chloride, zinc, selenium, iodine, and so on. Consequently, ash values can underestimate mineral contents. However, this error is small. Identifying individual minerals may be more meaningful and useful. If ash values are not very useful, why obtain them? They allow for calculations of nitrogen-free extract compared to DM.

\section{Crude fiber}

Crude fiber estimates the indigestible fraction of feed or those fractions of the feed that are fermented in the hindgut by microbes. Crude fiber includes different insoluble carbohydrates that are associated with the cell wall of plants and are resistant to the action of digestive enzymes. Crude fiber is made up of plant cell structural components, including cellulose, hemicelluloses, lignin, and pectin. For non ruminant animals, crude fiber is of little value energy-wise. However, it is important for maintaining hindgut health and microbial population. Crude fiber is important in the diets of ruminant animals, which can ferment a large portion of it. Crude fiber measures fermentable components of the feed. Crude fiber has little energy value but is important for gut health in pigs and poultry. Ruminant animals can ferment a large portion of crude fiber. To determine crude fiber in feed, a sample is dried, boiled in weak sulfuric acid $\left(1.25 \% \mathrm{H}_{2} \mathrm{SO}_{4}\right)$, and filtered. The residue is boiled in a weak alkali $(1.25 \% \mathrm{Na} \mathrm{OH})$ and filtered, and the remaining residue is dried and ashed. The difference between the filtered dried sample and ash is crude fiber. The two boiling processes simulate the $\mathrm{pH}$ conditions of the digestive tract, acidic in the stomach and alkaline in the small intestine. However, the enzymatic digestion in the digestive tract is not simulated in the procedure. Crude fiber tests underestimate true fiber in feed. A major problem with this procedure is that the acid and base solubilize some of the true fiber (particularly hemicelluloses, pectin, and lignin), and some cellulose is partially lost too. Hence crude fiber underestimates true fiber in the test material. The number, or value, obtained in this procedure, therefore, is practically meaningless. Most laboratories have phased out the crude fiber term and replaced it with the detergent fiber system.

\section{Neutral Detergent Fiber (NDF) and Acid Detergent Fiber (ADF)}

The detergent fiber system includes neutral detergent fiber and acid detergent fiber. NDF contains the major cell wall components, such as cellulose, hemicellulose, and lignin. It may also contain other very important components, such as cutin, and some proteins too. Hemicellulose, cellulose, and lignin are indigestible in non ruminants, while hemicellulose and cellulose are partially digestible (fermentable) in ruminants.

NDF fractionation is determined by boiling feed samples for one hour in a solution containing sodium lauryl sulfate and Ethylene Diamine Tetra Acetic Acid (EDTA) at pH 7.0. This detergent extracts soluble components of the feed (protein sugars, lipids, and organic acids), and the non soluble material is called NDF.

Acid detergent fiber is an estimate of cellulose + lignin in the feed sample. Hemicellulose, therefore, is estimated as NDF - ADF. This is not a perfect system, as there are contaminants 
in both $\mathrm{ADF}$ and NDF terms. ADF does the best job of describing the portion of feed it is designed to estimate (i.e., cellulose + lignin). The ADF and NDF terms have now largely replaced the crude fiber term. By using this method, we can better predict the digestibility of forages for animals. Nowadays, most laboratories use NDF and ADF analysis instead of crude fiber.

\section{Nitrogen-free extract}

The term Nitrogen-Free Extract (NFE) is a misnomer, as there is no nitrogen or extraction process in this procedure. Nitrogen-free extract is not determined analytically in the laboratory, as shown below. NFE supposedly represents the soluble carbohydrates of the feed, such as starch and sugar, and is the difference between the original sample weight and the sum of the weights of moisture (water), ether extract, crude protein, crude fiber, and ash. Therefore, it accumulates the errors of the other analytical systems. It is an overestimate of true NFE.

$\% \mathrm{NFE}=(\% \mathrm{DM}-(\%$ ether extract $+\%$ crude protein $+\%$ ash $+\%$ crude fiber $)$

\section{Statistical analysis}

The experimental design was a Complete Randomized Design (CRD) that had six treatments (plant species) with four replicates. The data on chemical analysis or nutrients' percent was analyzed using analysis of variance [13]. The data of in vitro DM and OM was also analyzed via analysis of variance. The difference among treatment means were detected using least significance difference $[13,14]$.

\section{Results and discussion}

\section{Chemical composition of the studied plants}

The chemical composition of range plants selected for this study is presented in Table 1 below. The dry matter was the highest in grass species; Schoenfeldia gracilis, Andropogon gayanus and Pennisetum pedicellatum) where it reached to $96.70,95.51$ and $95.03 \%$ respectively. The dry matter in herbaceous species Stylothanesis flavicans followed by Vigna sunhun that had $94.11 \%$ DM. Maximizing dry matter intake provides more nutrients to rumen microbes, which in turn provides more nutrients to animal production and composition, growth, reproduction and body condition [15]. Ash content was $9.4 \%$ in Vigna sunhum, 8.00 $\%$ for Pennisetum pedicellatum, $7.76 \%$ in Stylothanesis flavicans, $5.53 \%$ in Andropogon gayanus and $3.79 \%$ in Schoenfeldia gracilis without being affected by type of he flora. Accordingly organic matter, OM, was 92.91, 91.17, 87.75, 87.03 and $84.71 \%$ for Schoenfeldia gracilis, Andropogon gayanus, Stylothansis flavicans, Pennisetum pedicellatum and Vigna sunhum respectively. The most important constituent for the species studies was crude protein, CP where it was $13.45 \%, 10.00,7.74,4.69$ and $3.41 \%$ for Vigna sunhum, Stylothansis flavicans Pennisetum pedicellatum, Andropogon gayanus and Schoenfeldia gracilis, respectively. Ruminants have a minimum requirement for protein and energy to maintain normal body functions known as their 'maintenance' requirement which is approximately $2 \%$ of was significantly $(\mathrm{P}<0.05)$ lower and amounted to $95.51 \%$ for

their body weight [16-19]. The herbaceous species had higher Ether extract; 3.65 and $3.38 \%$ for Vigna sunhum and Stylothansis flavicans respectively while grasses were lower in their ether extract content with 58.35, 56.45, 49.45, 48.67 and $44.45 \%$ for Stylothansis flavicans, Vigna Sunhum, Pennisetum pedicellatum, Schoenfeldia gracilis and Andropogon gayanus respectively.

The Nitrogen Free Extract (NFE) fraction was found being 52.56, 45.11, 35.48, 34.83 and $32.6 \%$ for Andropogon gayanus, Schoenfeldia gracilis, Vigna sunhum, Pennisetum pedicellatum and Stylothansis flavicans respectively. In vitro dry matter and organic Matter digestibility of some Range Plants in North Kordofan coefficients are presented in Table 2. The IVDMD was found to $58.35,56.45,49.45,48.67$ and $44.45 \%$ for Amaranthesis flavican, Vigna Sunhum, Schoenfeldia gracilis, Andropogon gayanus and Pennisetum pedicellatum respectively. The in vitro organic matter digestibility coefficients were 58.61 57.55, 51.55, 49.61 and $46.65 \%$ for biomass of Amaranthesis flavican, Vigna Sunhum, Schoenfeldia gracilis, Andropogon gayanus and Pennisetum pedicellatum (Table 3 ).

\section{Conclusion}

The study concluded that range plants under investigation had different chemical components. Grasses were higher in fiber content and lower in their protein proportion. Some grasses (Andropogongayans) had substantial amounts of nitrogen free extracts and that could be attributed to their higher seeds. On the other hand legumes were superior in their protein content. In vitro dry matter and organic digestibility efficiency was increased by the increasing of protein contents and decreasing of fibers contents of the plant. These species of high nutritive

\begin{tabular}{|c|c|c|c|c|c|c|}
\hline Table 1: Chemical composition of some plants in North Kordofan State Sudan. \\
\hline Constituents & $\begin{array}{c}\text { Vigna } \\
\text { sunhum }\end{array}$ & $\begin{array}{c}\text { Pennisetum } \\
\text { pedicellatum }\end{array}$ & $\begin{array}{c}\text { Schoenfeldia } \\
\text { gracilis }\end{array}$ & $\begin{array}{c}\text { Stylothanesis } \\
\text { flavicans }\end{array}$ & $\begin{array}{c}\text { Andropogon } \\
\text { gayanus }\end{array}$ \\
\hline Moisture & 5.89 & 4.97 & 3.30 & 4.49 & 3.30 \\
\hline DM & 94.11 & 95.03 & 96.7 & 95.51 & 96.7 \\
\hline OM & 84.71 & 87.03 & 92.91 & 87.75 & 91.17 \\
\hline Protein & 13.45 & 7.74 & 3.41 & 10.00 & 4.69 \\
\hline Fiber & 32.40 & 41.79 & 43.30 & 41.50 & 46.01 \\
\hline Fat (EE) & 3.38 & 2.67 & 1.09 & 3.65 & 1.86 \\
\hline NFE & 35.48 & 34.83 & 45.11 & 32.6 & 52.56 \\
\hline NDF & 63.98 & 86.89 & 103.09 & 89.80 & 106.84 \\
\hline ADF & 40.95 & 53.80 & 47.67 & 47.05 & 52.98 \\
\hline ASH & 9.4 & 8.00 & 3.79 & 7.76 & 5.53 \\
\hline
\end{tabular}

DM: Dry Matter; OM: Organic Matter; EE: Ether Extraction; NFE: Nitrogen Free Extraction; NDF: Nutrient Detergent Fibre; ADF: Acid Detergent Fibre; ASH: Mineral

Table 2: In vitro dry matter and organic matter digestibility (\%) of some Range Plants in North Kordofan.

\begin{tabular}{|c|c|c|c|c|}
\hline Plant species & Local name & Dry matter & Organic matter & SE+ \\
\hline Vigna Sunhum & Lubia elghazal & 56.45 & 57.55 & 3.83 \\
\hline Stylothanesis flavicans & Natasha & 58.35 & 58.61 & 2.55 \\
\hline Pennisetum pedicellatum & Umdofofo & 44.45 & 46.65 & 5.49 \\
\hline Schoenfeldia gracilis & Danabelnaga & 49.45 & 51.55 & 1.32 \\
\hline Andropogon gayanus & Abuelrakhees & 48.67 & 49.61 & 5.41 \\
\hline
\end{tabular}

Citation: Musa Tibin MA, Musa Ibrahim BM, Mohamed Abdalla SE, Mohammed Abutaba YI, Ebrahiem MA, et al. (2021) Chemical composition and in vitro digestibility of some range plants. Open J Plant Sci 6(1): 094-098. DOI: https://dx.doi.org/10.17352/ojps.000040 
Table 3: Correlation between Protein Content and In Vitro Digestibility Coefficients.

\begin{tabular}{|c|c|c|c|c|c|}
\hline \multirow[t]{2}{*}{ Plant species } & \multirow[t]{2}{*}{ Local name } & \multicolumn{2}{|c|}{$\begin{array}{c}\text { Protein content-Dry } \\
\text { matter }\end{array}$} & \multicolumn{2}{|c|}{$\begin{array}{l}\text { Protein content- } \\
\text { organic matter }\end{array}$} \\
\hline & & $\mathbf{r}$ & LS & $\mathbf{r}$ & LS \\
\hline Vigna sunhum & $\begin{array}{l}\text { Lubia } \\
\text { elghazal }\end{array}$ & 0.860 & NS & 0.946 & NS \\
\hline $\begin{array}{l}\text { Stylothanthesis } \\
\text { flavicans }\end{array}$ & Natasha & 0.055 & NS & 1 & $\star \star$ \\
\hline $\begin{array}{l}\text { Pennisetum } \\
\text { pedicllatum }\end{array}$ & Umdofofo & 0.841 & NS & 0.673 & NS \\
\hline Schoenefoldia gracilis & Danab elnaga & -0.804 & NS & 0.187 & NS \\
\hline Andropogongayans & $\begin{array}{l}\text { Abu } \\
\text { elrakhees }\end{array}$ & 0.063 & NS & 0.71 & NS \\
\hline
\end{tabular}

Level; NS: Non Significant

value and in vitro digestibility may provide ruminants with the needed protein and energy, especially legumes.

\section{References}

1. Steinfeld H, Gerber P, Wassenaar T, Castel V, Rosales M, et al. (2006) Livestock's long shadow. FAO Rome. Link: https://bit.ly/3B27Xv6

2. Wright JS, Kaoru, Kitajima K, Kraft NJB, Reich PB, et al. (2010) Functional traits and the growth-mortality trade-off in tropical trees. Ecology 91: 3664-3674. Link: https://bit.ly/3F7u1GP

3. DeFries R, Rosenzweig C (2010) Toward a whole-landscape approach for sustainable land use in the tropics. Proc Natl Acad Sci 107: 19627-19632. Link: https://bit.ly/3ig3iOA

4. Ayantunde AA, De Leeuw J, Turner MD, Said M (2011) Challenges of assessing the sustainability of agropastoral systems. Livestock Science 139: 30-43. Link: https://bit.ly/3D4bYzL

5. Food and Agriculture Organization (FAO) (2009) The State of Food and Agriculture 2009 Livestock in the balance. Link: https://bit.ly/3zYdpgW

6. Godfray HCJ, Beddington JR, Crute IR, Haddad L, Lawrence D, et al. (2010) Food security: The challenge of feeding 9 billion people. Science 327: 812-818. Link: https://bit.ly/3oh2hK0

7. Wennekers S, Stel A, Thurik R, Reynolds PD (2005) Nascent Entrepreneurship and the Level of Economic Development. February 2005-Small Business Economics 30. Link: https://bit.ly/3mavT9a

8. Kemp DR, Michalk DL (2007) Pasture management technology for the $21^{\text {st }}$ century.

9. McDermott BM, Asai Y, Baucom JM, Jani SD, Castellanos $Y$, et al. (2010) Transgenic Labeling of Hair Cells in the Zebrafish Acousticolateralis System. Gene Expr Patterns 10: 113-118. Link: https://bit.ly/3F7tFQv

10. Jadalla JB, Khatir AA, Dawelbait EM, Ali SAM (2014) Relationship between some Growth Parameters and Browse Biomass Produced from Ailanthus excels Tree in Kordofan, Sudan. Greener Journal of Agronomy, Forestry and Horticulture 2: 008-013. Link: https://bit.ly/3CXK0p5

11. AOAC Association of Official Analytical Chemists- (2010) Official Methods of Analysis, $16^{\text {th }}$ ed. AOAC, Washington DC, USA.

12. Terrie PG (1994) Forever Wild: A Cultural History of Wilderness in the Adirondacks. Syracuse, NY: Syracuse University Press. Link: https://bit.ly/3kWo2Nf

13. Goering HK, Van Soest PJ (1970) Forage Fibre Analysis (Apparatus, reagents, procedures, and some application) Agric. Handbook 379 ARS-Washington, DC, USDA. Link: https://bit.ly/2ZKKtNd

14. Steel RGD, Torrie JH (1960) Principles and Procedures of Statistics. (With special Reference to the Biological Sciences). McGraw-Hill Book Company, New York, Toronto, London 481. Link: https://bit.ly/3DdGUh5

15. Snedecor GW, Cochran WA (1976) Statistical methods (6 ${ }^{\text {th }}$ ed.). Ames, lowa: The lowa State University Press. Link: https://bit.ly/3CVhbd1

16. Fustini M, Palmonari A, Canestrari G, Bonfante E, Mammi L, et al. (2017) Effect of undigested neutral detergent fiber content of alfalfa hay on lactating dairy cows: Feeding behavior, fiber digestibility, and lactation performance. J Dairy Sci 100: 4475-4483. Link: https://bit.ly/3utAcA7

17. Zhao GQ, Sheng NW, Yan FL, Eun CJ, Hak JK, et al. (2020) Comparison of Forage Quality, Productivity and $\beta$-carotene Conte nt according to Maturity of Forage Rye (Secale cereale L.). Journal of the Korean Society of Grassland and Forage Science 40: 123-130. Link: https://bit.ly/3uopPO5

18. Elobeid Meteorology Department (2020) Annual report. Elobeid Meteorology Department office. North Kordofan State, Elobaied, Sudan.

19. Sheikan locality (2020) Annual report. Strategy planning department. Sheikan locality- North Kordofan State, Elobaied, Sudan.

\section{Discover a bigger Impact and Visibility of your article publication with}

\section{Peertechz Publications}

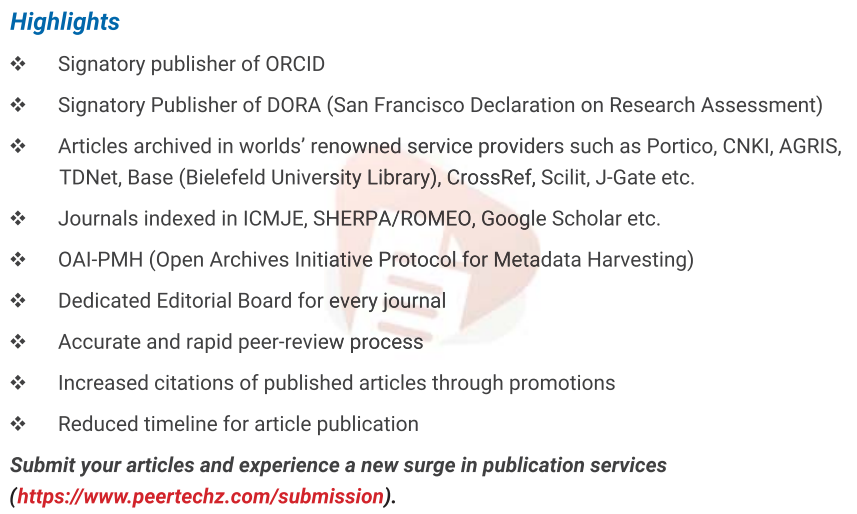

Peertechz journals wishes everlasting success in your every endeavours.

Citation: Musa Tibin MA, Musa Ibrahim BM, Mohamed Abdalla SE, Mohammed Abutaba Yl, Ebrahiem MA, et al. (2021) Chemical composition and in vitro digestibility of some range plants. Open J Plant Sci 6(1): 094-098. DOI: https://dx.doi.org/10.17352/ojps.000040 